\title{
Annual Report on the External Quality Assessment Scheme for Immunohematology Testing in Korea (2016)
}

\author{
Young Ae Lim and \\ Hyun Soo Cho \\ Department of Laboratory \\ Medicine, Ajou University \\ Hospital, Ajou University \\ School of Medicine, Suwon, \\ Korea
}

\author{
Corresponding author: \\ Young Ae Lim \\ Department of Laboratory \\ Medicine, Ajou University \\ Hospital, Ajou University School \\ of Medicine, 164 World cup-ro, \\ Yeongtong-gu, Suwon 16499, \\ Korea \\ Tel: +82-31-219-5786 \\ Fax: $+82-31-219-5778$ \\ E-mail: limyoung@ajou.ac.kr \\ pISSN: 2384-2458 \\ elSSN: 2288-7261
}

\begin{abstract}
We report here the 2016 results of surveys on an external quality assessment (EQA) for immunohematology testing in Korea carried out in 2016. The proficiency testing specimens were prepared at Ajou University Hospital, and the specimens were sent to participants biannually. The average accuracy rates ( $\mathrm{N}=$ the number of participants) for ten different test items on the regular survey were as follows: ABO typing, 98.9\%-99.7\% (N=627); $\mathrm{RhD}$ typing, 98.6\%-99.8\% ( $\mathrm{N}=607)$; crossmatching, 90.1\%-98.1\% ( $\mathrm{N}=454)$; ABO subtyping, 92.7\%-93.0\% ( $\mathrm{N}=42)$; Rh CcEe antigen testing, 97.8\%-100.0\% $(\mathrm{N}=46)$; weak D test, $70.8 \%-73.6 \%(\mathrm{~N}=91)$; antibody screening, 96.6\%-100.0\% ( $\mathrm{N}=267)$; direct antiglobulin test (DAT) using a polyspecific reagent, $92.2 \%-99.6 \%(\mathrm{~N}=49)$; DAT using an immunoglobulin G monospecific reagent, $84.1 \%-100.0 \%(\mathrm{~N}=68)$; DAT using a $\mathrm{C} 3 \mathrm{~d}$ monospecific reagent, 80.0\%-100.0\% ( $\mathrm{N}=68)$; antibody identification, $96.7 \%-99.1 \%(\mathrm{~N}=118)$; and $\mathrm{ABO}$ antibody titration, $82.4 \%-100.0 \%(\mathrm{~N}=42)$. Excellent results for the $2016 \mathrm{EQA}$ for immunohematology testing were obtained, except for those of the weak D test. The EQA for immunohematology testing in 2016 should be helpful for improving the quality of participating laboratories.
\end{abstract}

(J Lab Med Qual Assur 2017;39:107-116)

Key Words: Transfusion medicine, Assessment of quality, Laboratory proficiency testing

\section{서론}

수혈은 환자의 생명과 연관된 중요한 시술행위로 수혈 전 검 사는 정확성이 보증되어야 한다. 혈액은행검사에는 이러한 수 혈 전에 시행하여야 하는 혈액형검사와 비예기항체를 검출하 여야 하는 비예기항체 선별검사 및 교차시험이 포함되어 있다. 대부분 혈액은행에서 실시하고 있는 검사의 원리는 적혈구와 혈장 혹은 혈청을 이용한 면역혈구 응집법 검사이며, 다른 진 단검사의학 분야의 검사에 비하여 자동화가 가장 늦은 분야이 기도 하다. 따라서 이러한 검사들의 내부정도관리물질들은 널 리 상품화되어 있지도 않을뿐더러 상품화되어 있는 물질은 고 가이기 때문에 일반 검사실에서는 이들을 구입하여 사용하기 보다는 대부분 자가제조물질을 사용하고 있는 실정이다. 이러 한 이유로 혈액은행검사의 외부정도관리 참여는 검사의 신뢰 도를 평가할 수 있는 매우 중요한 과정이라고 할 수 있다.

대한임상검사정도관리협회에서는 2016년부터 새롭게 사업 프로그램을 구성하고 차세대 전산시스템을 개발하여 차세대
신빙도조사사업을 시행하게 되었다. 2015년까지 실시한 ABO 혈액형검사, $\mathrm{RhD}$ 혈액형검사, 교차시험검사, 직접항글로불린 검사, 비예기항체 선별검사 및 항체동정검사 등 총 6 가지 항 목과 추가로 실시한 시범항목이 포함되어 있었다 $[1,2]$. 그러 나 2016년부터는 수혈의학검사들이 다음과 같이 4개의 프로 그램으로 나뉘어 10 가지의 항목으로 시행하게 되었다. (1) 일 반수혈검사: $\mathrm{ABO}$ typing ( $\mathrm{ABO}$ 혈액형), $\mathrm{RhD}$ typing ( $\mathrm{RhD}$ 혈액형), crossmatching (교차시험); (2) 수혈항원검사, 특 수: $\mathrm{ABO}$ subtyping ( $\mathrm{ABO}$ 아형 혈액형), Rh CcEe antigen testing (Rh CcEe 항원검사), weak D test (약 D검사); (3) 수혈항체검사, 일반: antibody screening (비예기항체 선별검 사), direct antiglobulin test (직접항글로불린검사); (4) 수혈 항체검사, 특수: antibody identification (비예기항체 동정검 사), $\mathrm{ABO} \mathrm{Ab}$ titration ( $\mathrm{ABO}$ 항체 역가검사). 또한 각 프로 그램의 관리도 혈액은행분과에서 수혈의학 프로그램으로 바 뀌게 되었다.

이에 저자들은 2016년에 4개의 수혈의학 프로그램에서 실 


\section{Journal of LABORATORY MEDICINE and QUALITY ASSURANCE}

Young Ae Lim et al • Annual Report (2016) of Transfusion Medicine EQA

시한 10 가지의 검사항목에 대하여 2 차에 걸쳐 신빙도조사를 실시하였고, 기관별 검사방법에 대한 결과와 실시하였던 워크 솝 개최와 사업내용을 보고하고자 한다.

\section{재료 및 방법}

\section{1. 조사항목}

조사항목은 서론에서 언급한 바와 마찬가지로 $\mathrm{ABO}$ 혈액형 $\mathrm{RhD}$ 혈액형, 교차시험, $\mathrm{ABO}$ 아형 혈액형, $\mathrm{Rh} \mathrm{CcEe}$ 항원검 사, 약 $\mathrm{D}$ 검사, 비예기항체 선별검사, 직접항글로불린검사, 비 예기항체 동정검사, $\mathrm{ABO}$ 항체 역가검사의 10 가지 항목에 대 한 신빙도조사를 실시하였다.

\section{2. 외부신빙도 조사물질용 제조}

검체 제조는 2016년 차세대 신빙도조사사업을 위한 자가제 조물질 개발의 용역연구를 맡은 아주대학교병원에서 다음과 같이 제조하였다. 검체 제조에 사용된 혈액제제들은 대한적십 자사와 한마음 혈액원으로부터 생명윤리심의를 득한 후에 사 용하였다. 자가제조된 모든 검체는 검사자 2 인이 각각 검사하 여 결과 및 응집 정도를 확인하였다. 아주대학교병원에서 제조 되고 표식이 붙여진 외부신빙도조사물질들은 대한임상검사정 도관리협회로 운반되어 포장된 후 각 참여기관으로 발송되었 다. 외부신빙도조사 검체는 1 차 5 월 16일, 2 차는 10 월 31 일에 계약 택배를 이용하여 각각 발송하였다. 검사결과는 차세대 신 빙도조사사업 홈페이지에 입력하도록 하였다.

\section{1) 혈구부유액 제조}

신빙도조사 검사항목(각 회차당 검체 수)인 $\mathrm{ABO}$ 혈액형의 혈구형 검사(3개), $\mathrm{RhD}$ 혈액형(3개), 교차시험용 적혈구 부유 액(1개), $\mathrm{ABO}$ 아형 혈액형(1개), $\mathrm{Rh} \mathrm{CcEe}$ 항원검사(1개), 그 리고 약 $\mathrm{D}$ 검사(1개)를 위한 적혈구 부유액은 목적하고자 하는 혈액형을 가진 혈액을 혈구보존액인 EC Stabilizing solution (DiaMed GmbH, Cressier, Switerland)을 사용하여 3\%로 희석하였다. $\mathrm{ABO}$ 아형 혈액형과 약 $\mathrm{D}$ 검사 검체는 동일한 혈 액형을 가진 EDTA (ethylenediamine tetraacetic acid) 유래 검사용 검체들을 각각 혼주하여 사용하였고, 그 이외는 $\mathrm{CPDA}$ (citrate phosphate dextrose adenine)-1 혈액 백에서 분리된 농축적혈구를 사용하였다[1,2]. 혈액백의 혼주 시는 무균봉합 기로 연결하여 혼합한 다음 분주하였다.

2) 혈장용 검체 제조

$\mathrm{ABO}$ 혈청검사용은 혈구형과 동일한 $\mathrm{ABO}$ 혈액형, $\mathrm{ABO}$
항체 역가검사용은 $\mathrm{O}$ 형의 신선동결혈장을 사용하였다. 혈액 백의 혼주 시는 무균봉합기로 연결하여 혼합한 다음 분주하였 다. 그러나 2 차의 $\mathrm{ABO}$ 혈청검사용은 신선동결혈장 대신 혈청 형에 해당하는 항혈청을 식염수에 희석하여 사용하였다 [1,2].

\section{3) 재조합 혈장 검체 제조}

신빙도조사 검사항목(각 회차당 검체 수)인 교차시험(3개), 비예기항체 선별검사(3개), 비예기항체 동정검사(2개)는 항혈 청에 신선동결혈장 혹은 식염수를 이용하여 재조합하였다. 교 차시험 양성 검체는 항글로불린 단계에서만 검출되고 그 이외 의 단계에서는 검출되지 않거나 약하게 검출될 정도의 항혈청 의 항체 역가를 희석하여 검체를 제조하였는데, 상품화된 인간 유래 다클론성 항-D 항체(DiaMed $\mathrm{GmbH}$ 를 교차시험용 적 혈구 부유액과 반응시켰다 $[1,2]$. 항혈청 희석 시 1 차는 동일한 $\mathrm{ABO}$ 혈액형의 신선동결혈장, 2 차는 식염수에 희석하였다.

비예기항체 선별검사용 양성 검체로는 1 회차 때 항- $\mathrm{K}$ 항체 와 항-E 항체, 2 회차 때 항- $\mathrm{e}$ 항체를 발송하였고, 동정용 양성 검체로는 1 회차 항- $-\mathrm{Fy}^{\mathrm{a}}$ 항체와 항- $\mathrm{N}$ 항체, 2 회차 때 항- $\mathrm{K}$ 항 체와 항-e 항체를 발송하였다. 검체는 항혈청 시약을 각각 희 석하여 사용하였는데 사용된 항혈청 시약의 종류는 각각 다 클론성항-Fy ${ }^{a}$ 항체 $(\mathrm{CE}$ Diagnostika $\mathrm{GmbH}$, Eschelbronn, Germany), 단클론성 항-N 항체(CE Diagnostika $\mathrm{GmbH}$ ), 다클론성 항-K 항체 $(\mathrm{CE}$ Diagnostika $\mathrm{GmbH})$, 단클론성 항-e 항체(Diagast, Parc Eurasanté, France)였다. 희석 시는 교 차시험용 재조합 혈장 검체 제조와 마찬가지로 1 차는 동일한 $\mathrm{ABO}$ 혈액형의 신선동결혈장, 2 차는 식염수에 희석하였다. 비 예기항체 선별검사용 음성 검체는 신선동결혈장에 1 차는 비예 기항체 음성인 신선동결혈장을 첨가하였고, 2 차는 식염수만을 사용하였다 [1,2].

\section{4) 직접항글로불린검사용 혈구 제조}

양성 직접항글로불린검사용 혈구는 상품화된 감작혈구 immunoglobulin G (IgG) Coated Cell (Mirr Scitech, Seoul, Korea)를 이용하였고, 음성 직접항글로불린검사용 혈구는 직 접항글로불린 검사결과 음성인 적혈구를 혈구보존액인 $\mathrm{EC}$ Stabilizing solution (DiaMed GmbH)에 3\% 희석하여 이용 하였다.

\section{3. 결과 판정 및 분석 검체}

정답률 산정 시 동일 검사종목에 대하여 일부 검체에 대하여 답변을 하지 않거나 모든 검체에 대하여 일부만 답변한 경우는 (예, 응집강도만 표시하고 최종 판정을 하지 않은 경우) Code 


\section{Journal of LABORATORY MEDICINE and QUALITY ASSURANCE}

Young Ae Lim et al • Annual Report (2016) of Transfusion Medicine EQA

712 로 간주하고 이는 오답으로 평가하였다. 또한 교차시험이 나 해당검사를 시행하기에 적절하지 않은 슬라이드법은 분석 에서 제외하였다. 교차시험의 경우 음성으로 적합 판정을 한 검체에 대해서는 응집이 없다고 보고한 경우만 정답으로 간주 하였다. Rh CcEe 항원검사와 직접항글로불린검사의 경우 $1+$ 이상을 양성으로 간주하여 양성 검체의 정답률을 산정하였다. $\mathrm{ABO}$ 항체 역가검사의 허용범위는 참여기관이 10 기관 이상인 검사법에 대하여 최빈도와 상하 한 단계씩 추가하였고 이 범 위에 속하는 참여기관이 $80 \%$ 를 넘지 않을 경우에는 최빈도와 상하 단계 근처의 빈도수가 많은 단계를 더 추가하여 결정하였 다.

\section{4. 워크숍 개최}

혈액은행 실기 워크솝은 혈액은행분과 단독으로 주관하여 총 1 회의 워크숍을 개최하였는데, 워크솝에 대한 공지는 개최 전에 홈페이지의 게시판과 문자수신 등을 이용하였다.

\section{결과}

\section{1. 일반수혈검사}

1) $\mathrm{ABO}$ 와 $\mathrm{RhD}$ 혈액형

$\mathrm{ABO}$ 혈액형검사는 2 차에 걸쳐 총 6 개의 검체로 실시하였 고, 정답률은 98.9\%-99.7\%를 나타냈다(Table 1). 1차(2차) 의 혈구형 검사법은 슬라이드법 $49.8 \%$ (48.0\%), 시험관법 $42.8 \%$ (46.4\%) 순이었으며, 1차(2차)의 혈청형검사법은 시 험관법이 $85.0 \%$ (87.5\%), 슬라이드법 9.2\% (8.2\%) 순으로 나타났다. $\mathrm{RhD}$ 혈액형검사도 2 차에 걸쳐 총 6 개의 검체로 실 시하였고, 정답률은 98.6\%-99.8\%를 나타냈다(Table 2). 1차 (2차)의 검사법은 1 차에서는 시험관법이 $51.1 \%$ (55.3\%), 슬 라이드법 40.3\% (38.7\%) 순이었다.

\section{2) 교차시험}

교차시험검사는 2 차에 걸쳐 총 6 개의 검체가 사용되었으며, 적합 검체는 $96.7 \%-98.1 \%$, 부적합 검체는 $90.1 \%-94.1 \%$ 의 교차시험 판정 정답률을 보여 $95.8 \%$ 의 평균 정답률을 보였다. 각 단계별 정답률을 분석한 결과, 적합 검체가 $96.1 \%-100.0 \%$

Table 1. Number (\%) of participants in proficiency tests for ABO blood grouping in 2016

\begin{tabular}{|c|c|c|c|c|c|c|c|c|c|}
\hline Trial & Specimen & Total & A & B & $\mathrm{AB}$ & $\mathrm{O}$ & Dis & NA & $\begin{array}{l}\text { Intended } \\
\text { response }\end{array}$ \\
\hline \multirow[t]{3}{*}{1} & BB-16-01+BB-16-04 & $641(100.0)$ & $634(98.9)$ & & $2(0.3)$ & & $4(0.6)$ & $1(0.2)$ & A \\
\hline & BB-16-02+BB-16-05 & $641(100.0)$ & & & $1(0.2)$ & $639(99.6)$ & & $1(0.2)$ & $\mathrm{O}$ \\
\hline & BB-16-03+BB-16-06 & $641(100.0)$ & & $1(0.2)$ & $635(99.1)$ & $2(0.3)$ & $2(0.3)$ & $1(0.2)$ & $\mathrm{AB}$ \\
\hline \multirow[t]{3}{*}{2} & BB-16-07+BB-16-10 & $613(100.0)$ & $1(0.2)$ & $619(99.5)$ & & & $2(0.3)$ & & B \\
\hline & BB-16-08+BB-16-11 & $613(100.0)$ & & & $1(0.2)$ & $621(99.7)$ & $1(0.2)$ & & $\mathrm{O}$ \\
\hline & BB-16-09+BB-16-12 & $613(100.0)$ & $618(99.2)$ & $1(0.2)$ & & & $3(0.4)$ & $1(0.2)$ & A \\
\hline
\end{tabular}

Values are presented as number (\%), unless otherwise stated.

Abbreviations: Dis, discrepancy between cell typing and serum typing; NA, not available.

Table 2. Number (\%) of participants in proficiency tests for RhD typing in 2016

\begin{tabular}{cccccccc}
\hline Trial & Specimen & Total & Positive & Variant & Negative & NA & Intended response \\
\hline 1 & BB-16-01 & $614(100.0)$ & $5(0.8)$ & $2(0.3)$ & $605(98.6)$ & $2(0.3)$ & Negative \\
& BB-16-02 & $614(100.0)$ & $606(98.7)$ & & $1(1.3)$ & 0 & Positive \\
& BB-16-03 & $614(100.0)$ & $611(99.5)$ & $1(0.2)$ & $2(0.3)$ & $1(0.2)$ & Positive \\
2 & BB-16-07 & $599(100.0)$ & $598(99.8)$ & & & $1(0.2)$ & Positive \\
& BB-16-08 & $599(100.0)$ & $598(99.8)$ & & $3(0.5)$ & $594(99.2)$ & Negative \\
\hline
\end{tabular}

Values are presented as number (\%), unless otherwise stated.

Abbreviation: NA, not available. 
이고, 부적합 검체가 $66.7 \%-100.0 \%$ 로 부적합 검체에서 오답 률이 더 높았다. 정답률은 검사기관이 10 개 미만인 검사법을 제외하고는 미세원주응집법이 $99.1 \%$ 로 가장 높았고 항글로 불린 단계의 시험관법은 $95.5 \%$ 였다(Table 3 ). 검사법은 최종 판정을 실시한 기관 중 중복 시행을 포함하여 시험관법이 1차 (2차)가 각각 85.6\% (87.0\%)로 가장 많이 사용하는 방법으로 나타났으며, 미세원주응집법 $27.4 \%$ (28.6\%)를 차지하였다.

\section{2. 수혈항원검사}

1) $\mathrm{ABO}$ 아형 혈액형

1 차 검체는 $\mathrm{A}_{2} \mathrm{Bw}$ 형으로 $95.2 \%$ (40/42)의 정답률을 보였는 데 항-B 시약과의 반응에서 $2+$ 이하와 혼합시야를 보고한 기 관은 $87.1 \%$, 항-H 시약과의 반응에서 $3+$ 이상을 보고한 기 관은 $60.7 \%$ 였다 2차 검체는 $\mathrm{Bw}$ 형으로 $92.7 \%$ (38/41)에서 정답률을 보였는데 항-B 시약과의 반응에서 $2+$ 이하와 혼합 시야를 보고한 기관은 $87.8 \%$, 항-H 시약과의 반응에서 $3+$ 이상을 보고한 기관은 $75.0 \%$ 였다(Table 4).

\section{2) Rh CcEe 항원검사}

$\mathrm{Rh} \mathrm{CcEe}$ 항원검사는 45개(E 항원은 46개) 기관에서 참 여하였다. 1 차 검체는 $\mathrm{CcEe}$ 항원이 양성으로 모든 기관에서 $100 \%$ 정답률을 보였다. $\mathrm{Ce}$ 항원만 양성인 2 차 검체는 $\mathrm{E}$ 항원 $2.2 \% 1+$ 와 c 항원 $2.2 \%$ trace를 보인 경우를 제외하고는 모 두 정답을 나타내었다(Table 5).

\section{3) 약 $D$ 검사}

약 $\mathrm{D}$ 검사는 1 차 $70.8 \%, 2$ 차는 $73.6 \%$ 에서 의도한 변이형 $\mathrm{D}$ 로 보고하였으나, $25.8 \%$ 와 $23.1 \%$ 에서는 $\mathrm{RhD}$ 혈액형검사에 서는 음성이고 약 $\mathrm{D}$ 검사에서 양성이었음에도 불구하고 $\mathrm{RhD}$ 양성으로 보고하였다(Table 6).

\section{3. 일반 수혈항체검사}

\section{1) 비예기항체 선별검사}

비예기항체 선별검사는 1 차와 2 차의 경우 모두 2 개의 양성 검체와 1 개의 음성 검체를 발송하였는데, 2 차때 발송된 2 개 의 양성 검체의 항체 역가가 급격히 저하되어 실제 평가기관에 서 검사 당시 검출되지 않음이 확인되어 평가에서 이들을 제 외하였다. 이 검체들을 제외한 음성 검체의 정답률은 $99.6 \%$ $100.0 \%$ 였으나 양성 검체의 정답률은 $96.6 \%-100.0 \%$ 였다 (Table 7). 1차(2차)의 항체선별 검사법은 미세원주응집법 $90.6 \%$ (91.8\%), 시험관법 4.2\% (4.1\%)를 차지하였다.

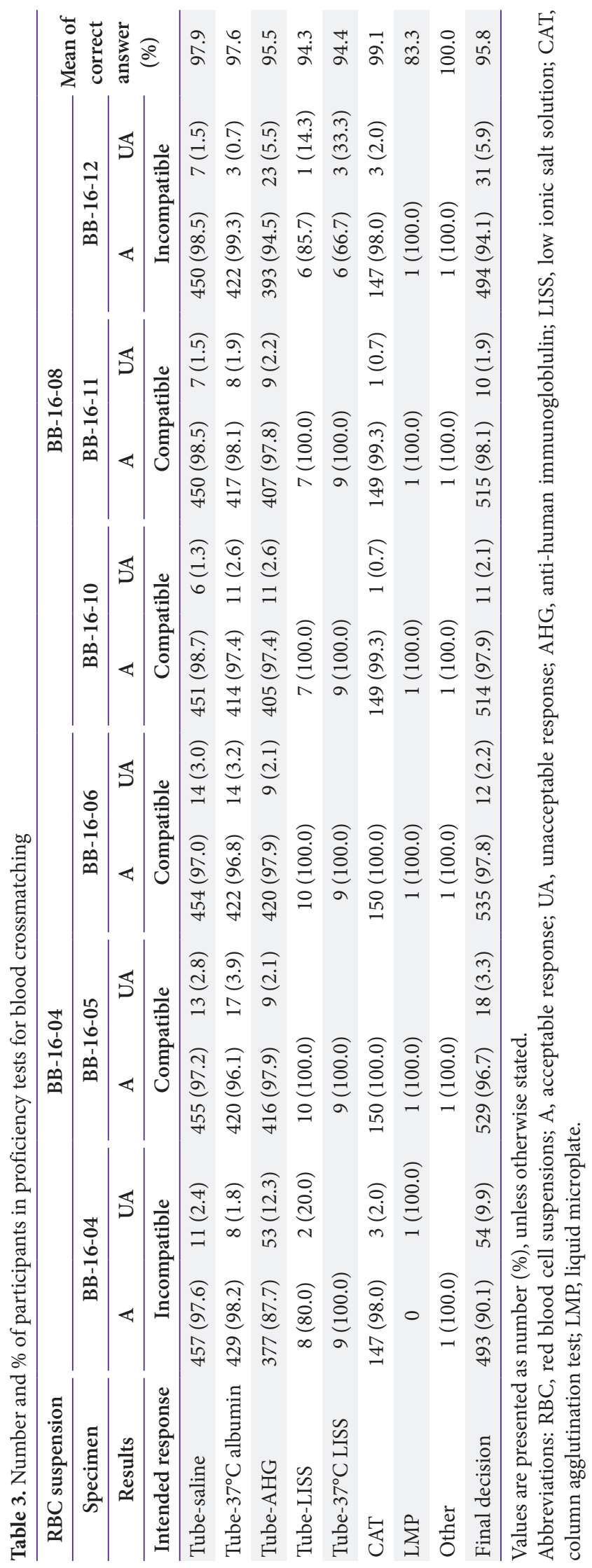

J Lab Med Qual Assur 2017;39:107-116

www.jlmqa.org 
Journal of LABORATORY MEDICINE and QUALITY ASSURANCE

Young Ae Lim et al • Annual Report (2016) of Transfusion Medicine EQA

Table 4. Number (\%) of participants in proficiency tests for ABO subtyping

\begin{tabular}{|c|c|c|c|c|c|c|c|}
\hline \multirow{3}{*}{$\begin{array}{l}\text { Trial (specimen) } \\
1 \text { (BGS-16-01) }\end{array}$} & \multirow{3}{*}{$\begin{array}{c}\text { RBC agglutination } \\
\text { Total }\end{array}$} & \multicolumn{4}{|c|}{ Anti-sera } & \multirow{2}{*}{\multicolumn{2}{|c|}{ ABO subgroup }} \\
\hline & & \multirow{2}{*}{$\begin{array}{c}\text { Anti-A } \\
42\end{array}$} & \multirow{2}{*}{$\begin{array}{c}\text { Anti-B } \\
42\end{array}$} & \multirow{2}{*}{$\begin{array}{c}\text { Anti-A } \\
42\end{array}$} & \multirow{2}{*}{$\begin{array}{c}\text { Anti-H } \\
28\end{array}$} & & \\
\hline & & & & & & $\mathrm{A}_{2}$ & $1.0(2.4)$ \\
\hline & Negative & & $1(2.4)$ & $41(97.6)$ & & $\mathrm{A}_{1} \mathrm{Bw}$ & $1.0(2.4)$ \\
\hline & \pm & & $2(4.8)$ & & & $\mathrm{A}_{2} \mathrm{Bw}^{*}$ & $40(95.2)$ \\
\hline & $1+$ & & $10(23.8)$ & $1(2.4)$ & & & \\
\hline & $2+$ & & $15(35.7)$ & & $11(39.3)$ & & \\
\hline & $3+$ & $5(11.9)$ & $3(7.1)$ & & $11(39.3)$ & & \\
\hline & $4+$ & $37(88.1)$ & $2(4.8)$ & & $6(21.4)$ & & \\
\hline & MF & & $9(21.4)$ & & & & \\
\hline \multirow[t]{8}{*}{2 (BGS-16-02) } & Total & 41 & 41 & 37 & 24 & $\mathrm{~A}_{2}$ & $1(2.4)$ \\
\hline & Negative & $41(100.0)$ & & $37(100.0)$ & & $\mathrm{B}$ & $2(4.9)$ \\
\hline & \pm & & $1(2.4)$ & & & $\mathrm{Bw}^{*}$ & $38(92.7)^{*}$ \\
\hline & $1+$ & & $4(9.8)$ & & $1(4.2)$ & & \\
\hline & $2+$ & & $15(36.6)$ & & $5(20.8)$ & & \\
\hline & $3+$ & & $5(12.2)$ & & $4(16.7)$ & & \\
\hline & $4+$ & & & & $14(58.3)$ & & \\
\hline & MF & & $16(39.0)$ & & & & \\
\hline
\end{tabular}

Values are presented as number (\%), unless otherwise stated.

Abbreviations: RBC, red blood cell suspensions; MF, mixed field agglutination.

${ }^{*}$ Intended responses for $\mathrm{ABO}$ subgrouping.

Table 5. Number (\%) of participants in proficiency tests for Rh CcEe antigen typing

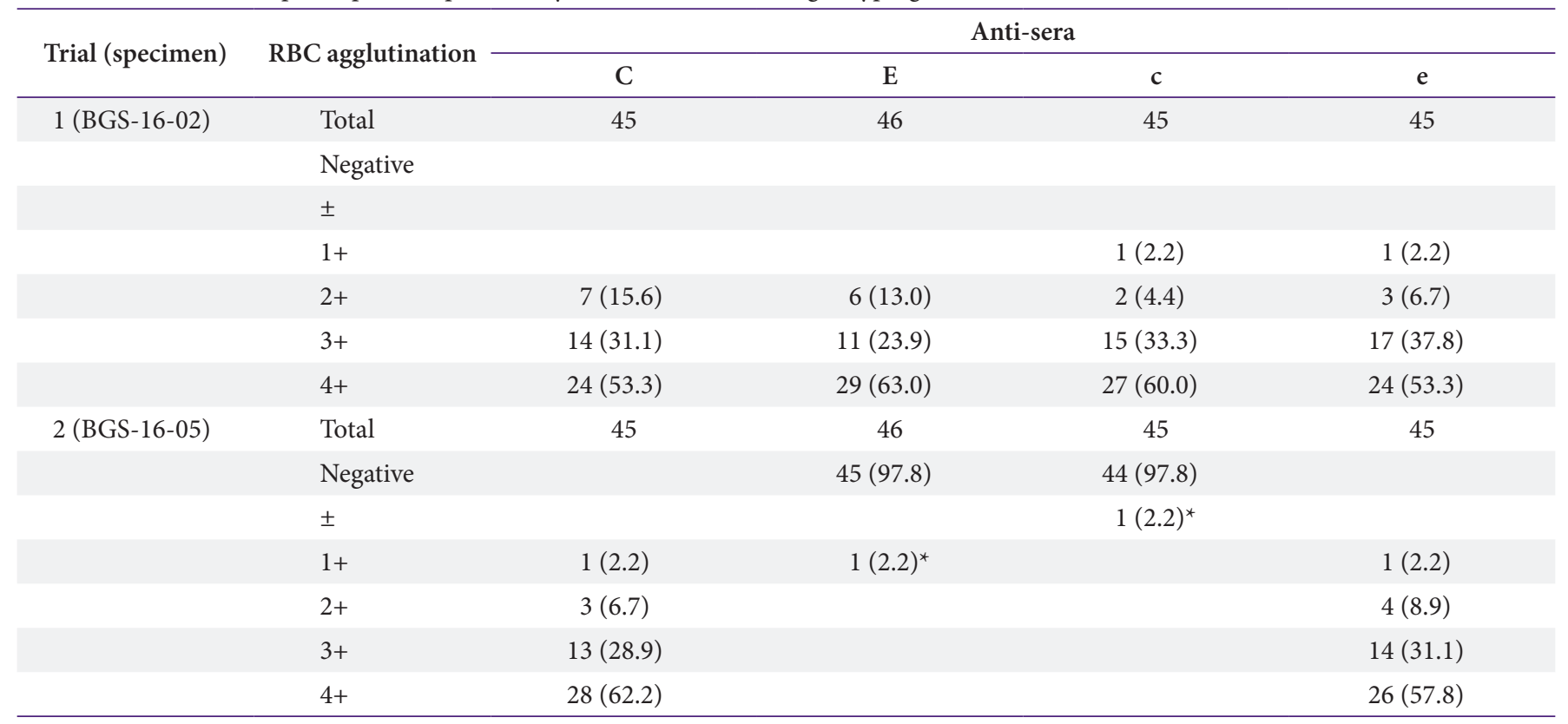

Values are presented as number (\%), unless otherwise stated.

Abbreviation: RBC, red blood cell suspensions.

${ }^{\star}$ Unacceptable responses for $\mathrm{Rh} \mathrm{CcEe}$ antigen test. 


\section{Journal of LABORATORY MEDICINE and QUALITY ASSURANCE}

Young Ae Lim et al • Annual Report (2016) of Transfusion Medicine EQA

\section{2) 직접항글로불린검사}

직접항글로불린검사는 2 차에 걸쳐 총 6 개의 검체가 사용되 었는데, 항글로불린 시약에 따른 정답률은 다특이성 $92.2 \%$ $99.6 \%, \mathrm{IgG}$ 단특이성 $84.1 \%-100.0 \%$, 그리고 C3d 단특이 성 80.0\%-100.0\%였다. 양성(음성) 검체의 정답률은 다특 이성 92.2\%-97.2\% (93.5\%-99.6\%), 단특이성 IgG 85.5\%95.5\% (84.1\%-100.0\%), 그리고 단특이성 C3d 80.0\%$89.6 \%$ (85.7\%-100.0\%)로 음성 검체의 정답률에 비하여 낮 았다(Table 8). 다특이성 항글로불린 시약을 이용한 검사법은 미세원주응집법이 1차(2차)가 각각 $62.3 \%$ (64.4\%)씩으로 가 장 많이 사용하였으며 시험관법이 $33.2 \%$ (34.4\%)으로 나타 났다.

Table 6. Number (\%) of participants in proficiency tests for weak D test

\begin{tabular}{|c|c|c|c|c|}
\hline \multirow{2}{*}{$\begin{array}{c}\text { Trial } \\
\text { (specimen) }\end{array}$} & \multicolumn{2}{|c|}{1 (BGS-16-03) } & \multicolumn{2}{|c|}{2 (BGS-16-06) } \\
\hline & $\mathrm{RhD}$ & Weak D & $\mathrm{RhD}$ & Weak D \\
\hline Total & 90 & 90 & 91 & 91 \\
\hline Negative & $83(92.2)$ & $3(3.3)$ & $86(94.5)$ & $3(3.3)$ \\
\hline \pm & $3(3.3)$ & & $5(5.5)$ & \\
\hline $1+$ & $1(1.1)$ & $2(2.2)$ & & $6(6.6)$ \\
\hline $2+$ & $2(2.2)$ & $22(24.4)$ & & $25(27.5)$ \\
\hline $3+$ & $1(1.1)$ & $44(48.9)$ & & $42(46.2)$ \\
\hline $4+$ & & $19(21.1)$ & & 15 (16.5) \\
\hline D positive & \multicolumn{2}{|c|}{$23(25.8)$} & \multicolumn{2}{|c|}{$21(23.1)$} \\
\hline D variant ${ }^{*}$ & \multicolumn{2}{|c|}{$63(70.8)$} & \multicolumn{2}{|c|}{67 (73.6) } \\
\hline D negative & \multicolumn{2}{|c|}{$3(3.4)$} & \multicolumn{2}{|c|}{$3(3.3)$} \\
\hline
\end{tabular}

Values are presented as number (\%), unless otherwise stated.

${ }^{\star}$ Intended responses for weak D testing.

\section{4. 특수 수혈항체검사}

\section{1) 비예기항체 동정검사}

항체 동정검사의 정답률은 anti-N과 anti-Fy는 각각 $96.7 \%$, anti-K는 99.1\%였으나, 2차때 발송된 검체 중 anti-e 검체의 항체 역가가 급격히 저하되어 실제 평가기관에서 검 사 당시 검출되지 않음에 확인되어 평가에서 이를 제외하였다 (Table 9). 특히 1차 시 모든 검체에서 검출된 anti-N과 anti$\mathrm{Fy}^{\mathrm{a}}$ 항체를 하나의 검체결과에 $\mathrm{anti}-\mathrm{N}+\mathrm{anti}^{-\mathrm{Fy}^{\mathrm{a}}}$ 입력한 기관 의 결과는 오답으로 처리하였다.

\section{2) $\mathrm{ABO}$ 항체 역가검사}

각 방법별 $\mathrm{ABO}$ 항체 역가검사결과는 Table 10 과 같으며 허용범위는 굵은 글씨로 표시하였다. Anti-A의 경우 허용범 위에 드는 참여기관 비율은 1 차와 2 차는 각각 시험관 즉시원 침법은 모두 82.9\% (34/41)와 85.7\% (36/42), 시험관 실온배 양법 93.3\% (14/15)와 82.4\% (14/17), 시험관 항글로불린법 94.4\% (17/18)과 83.3\% (15/18), 미세원주응집 항글로불린 법 100.0\% (21/21)과 95.8\% (23/24)로 가장 높았다. Anti-B 의 경우 허용범위에 드는 참여기관 비율은 1 차와 2 차는 각각 시험관 즉시원침법은 모두 95.1\% (39/41)과 81.0\% (34/42), 시험관 실온배양법 $100.0 \%$ (15/15)과 94.1\% (16/17)로 가 장 높았고, 시험관 항글로불린법 94.4\% (17/18)과 83.3\% (15/18), 미세원주응집 항글로불린법 $95.2 \%$ (20/21)과 95.8\% (23/24) 였다. IgM 측정을 위하여 2012년 표준안으로 제시된 시험관 실온배양법에 비하여 시험관 즉시원침법을 사 용하는 기관이 더 많았고, $\operatorname{IgG}$ 측정을 위해서는 미세원주응집 법, 항글로불린법을 사용하는 기관이 더 많았다.

\section{5. 워크숍 개최}

수혈 전 검사 실기 워크숍을 2016년 8월 26일(금) 오전 9시

Table 7. Number (\%) of participants in proficiency tests for antibody screening

\begin{tabular}{|c|c|c|c|c|c|}
\hline \multirow{2}{*}{ Trial } & \multirow{2}{*}{ Specimen } & \multirow{2}{*}{ Number } & \multicolumn{2}{|c|}{ Results } & \multirow{2}{*}{ Intended response } \\
\hline & & & Positive & Negative & \\
\hline \multirow[t]{3}{*}{1} & BBG-16-01 & 266 & $266(100.0)$ & & Positive \\
\hline & BBG-16-02 & 266 & $257(96.6)$ & $9(3.4)$ & Positive \\
\hline & BBG-16-03 & 266 & $1(0.4)$ & 265 (99.6) & Negative \\
\hline \multirow[t]{3}{*}{2} & BBG-16-07 & 267 & $267(100.0)$ & & Negative \\
\hline & BBG-16-08 & 267 & $6(2.2)$ & $261(97.8)$ & Positive $^{*}$ \\
\hline & BBG-16-09 & 267 & $39(14.6)$ & $228(85.4)$ & Positive \\
\hline
\end{tabular}

Values are presented as number (\%), unless otherwise stated.

${ }^{*}$ Not evaluated due to the poor quality of specimens. 
Journal of LABORATORY MEDICINE and QUALITY ASSURANCE

Young Ae Lim et al • Annual Report (2016) of Transfusion Medicine EQA

Table 8. Number (\%) of participants in proficiency tests for the direct antiglobulin test

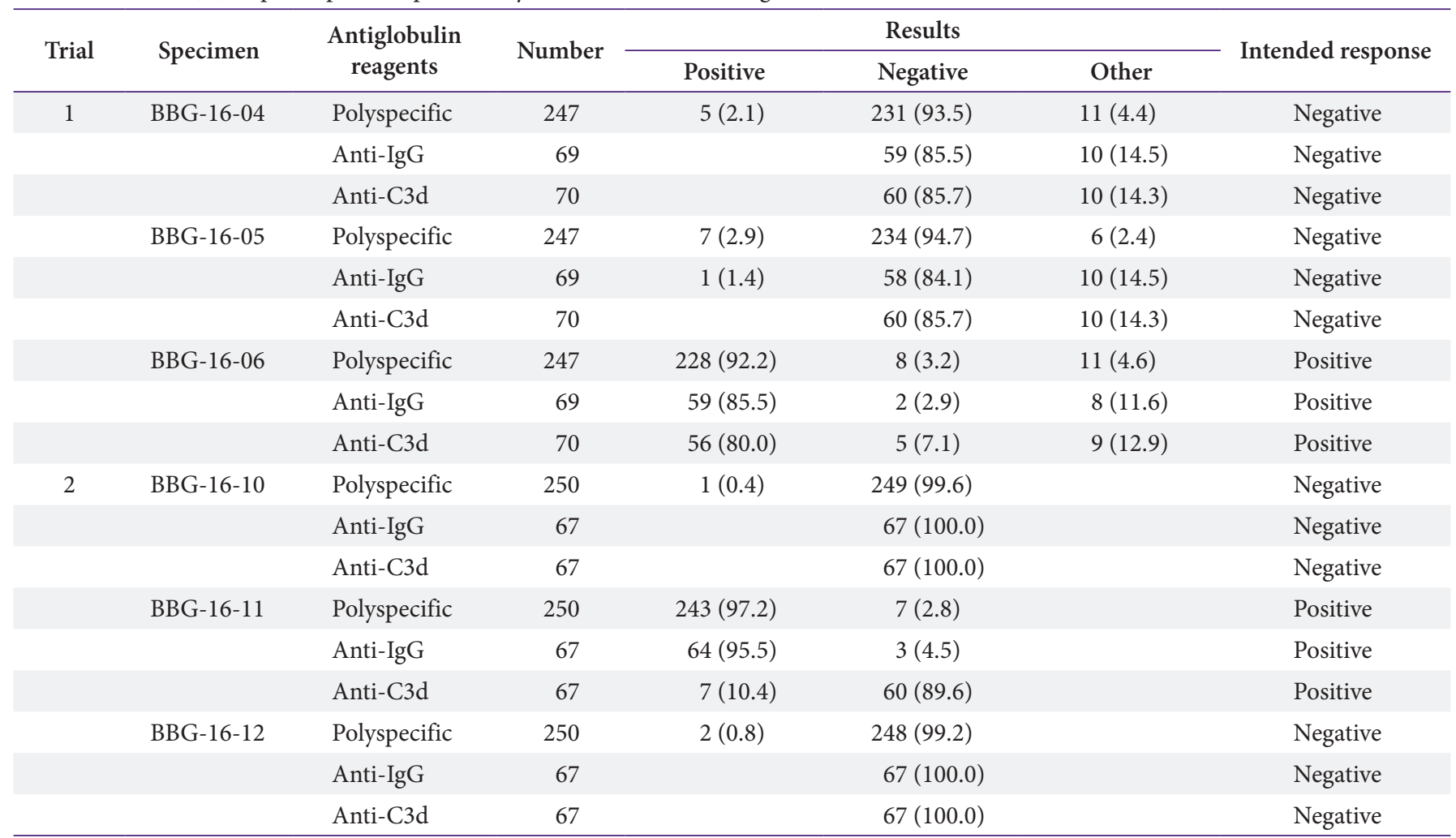

Values are presented as number (\%), unless otherwise stated.

Abbreviation: IgG, immunoglobulin G.

Table 9. Number (\%) of participants in proficiency tests for antibody identification

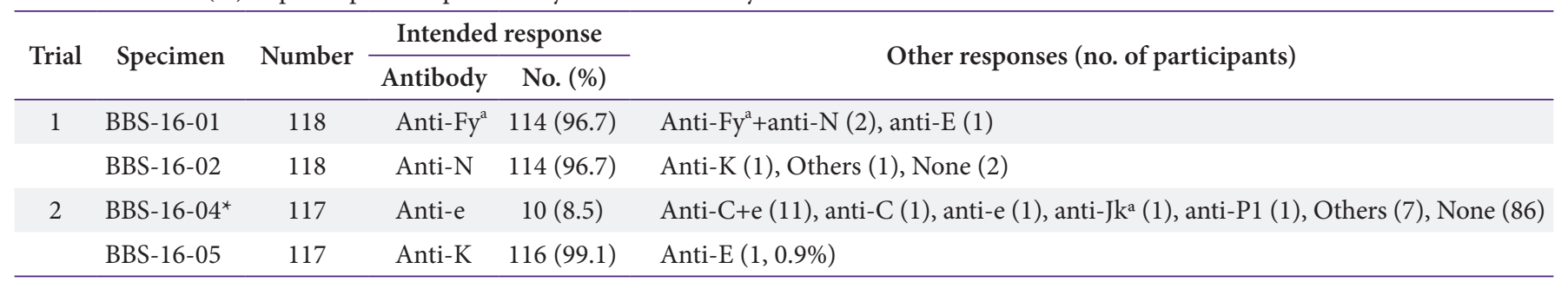

${ }^{*}$ Not evaluated due to the poor quality of specimens.

부터 17시까지 아주대학교 의과대학 송재관학생실습실에서 1 회만 개최하였다. 내용은 $\mathrm{ABO}$ 아형, $\mathrm{RhD}$ 변이형 검체검사 검출법, 비예기항체 검출원리, 비예기항체 선별과 동정에 대하 여 실시하였다. 오전에는 이론강의를 실시하였는데 68 명이 참 석하였고, 오후에는 실습이 이루어졌으며 50명이 참석하였다.

\section{고찰}

일반수혈검사에 포함된 $\mathrm{ABO}$ 와 $\mathrm{RhD}$ 혈액형, 교차시험과 $\mathrm{ABO}$ 항체 역가검사는 작년에 비하여 참여기관 수는 증가하
였으나 나머지 검사종목들의 참여하는 기관 수는 감소하였다. 이러한 현상은 기존에 검사종목이 4개의 프로그램으로 나뉘면 서 각 프로그램마다 별도의 가격이 책정되었기 때문에 기존에 다른 검사종목에도 참여하였던 기관들 중 일부가 일반수혈검 사를 제외한 나머지 검사항목들을 신청하지 않았기 때문으로 해석된다. 특히 $\mathrm{ABO}$ 와 $\mathrm{RhD}$ 혈액형의 경우 전년도 참여기관 은 평균 543기관에서 2016년도에 627기관으로 매우 증가하였 다.

$\mathrm{ABO}$ 와 $\mathrm{RhD}$ 혈액형 정답률은 전년도에 비하여 약간 저하 되었는데, 이는 신규기관의 증가와 1 차의 경우 일부 기관에서 


\section{Journal of LABORATORY MEDICINE and QUALITY ASSURANCE}

Young Ae Lim et al • Annual Report (2016) of Transfusion Medicine EQA

Table 10. Number of participants in proficiency tests for ABO antibody titration

\begin{tabular}{|c|c|c|c|c|c|c|c|c|c|c|c|}
\hline \multirow{2}{*}{$\begin{array}{c}\text { Technique } \\
(\% \text { of allowable range })^{\star}\end{array}$} & \multirow{2}{*}{ Trial } & \multirow{2}{*}{ Number } & \multicolumn{9}{|c|}{ Titer } \\
\hline & & & 2 & 4 & 8 & 16 & 32 & 64 & 128 & 256 & 512 \\
\hline \multicolumn{12}{|l|}{ Anti-A } \\
\hline Tube-IS (82.9) & 1 & 41 & & 4 & 10 & 17 & 7 & 1 & 1 & 1 & \\
\hline Tube-RT (93.3) & & 15 & & & & 2 & 12 & & 1 & & \\
\hline Tube-AHG (94.4) & & 18 & & & 1 & 2 & 13 & 2 & & & \\
\hline Tube-AHG, DTT & & 6 & & & 5 & 1 & & & & & \\
\hline CAT-RT & & 7 & & & 3 & 2 & 2 & & & & \\
\hline CAT-AHG (100.0) & & 21 & & & 3 & 8 & 8 & 2 & & & \\
\hline CAT-AHG, DTT & & 4 & & 1 & & 1 & 1 & 1 & & & \\
\hline Others & & 2 & & 1 & 1 & & & & & & \\
\hline Tube-IS (85.7) & 2 & 42 & & 1 & 3 & 9 & 19 & 8 & 2 & & \\
\hline Tube-RT (82.4) & & 17 & & & & 3 & 4 & 9 & 1 & & \\
\hline Tube-AHG (83.3) & & 18 & & & 1 & 2 & & 9 & 6 & & \\
\hline Tube-AHG, DTT & & 5 & & & & & 1 & 3 & 1 & & \\
\hline CAT-RT & & 7 & & & & 4 & 1 & 2 & & & \\
\hline CAT-AHG (95.8) & & 24 & & & & & 1 & 10 & 7 & 5 & 1 \\
\hline CAT-AHG, DTT & & 5 & & & & & & 4 & 1 & & \\
\hline \multicolumn{12}{|l|}{ Anti-B } \\
\hline Tube-IS (95.1) & 1 & 41 & 5 & 12 & 18 & 4 & 1 & 1 & & & \\
\hline Tube-RT (100.0) & & 15 & & 1 & 6 & 6 & 2 & & & & \\
\hline Tube-AHG (94.4) & & 18 & & & 1 & 3 & 11 & 3 & & & \\
\hline Tube-AHG, DTT & & 6 & & 2 & 1 & 3 & & & & & \\
\hline CAT-RT & & 7 & & & & 4 & 1 & 2 & & & \\
\hline CAT-AHG (95.2) & & 21 & & & & 7 & 10 & 3 & 1 & & \\
\hline CAT-AHG, DTT & & 4 & & & 1 & 1 & 2 & & & & \\
\hline Others & & 1 & 1 & & & & & & & & \\
\hline Tube-IS (81.0) & 2 & 42 & & 1 & 6 & 11 & 15 & 8 & 1 & & \\
\hline Tube-RT (94.1) & & 17 & & & & 3 & 5 & 8 & & 1 & \\
\hline Tube-AHG (83.3) & & 18 & & & 1 & 2 & 1 & 10 & 4 & & \\
\hline Tube-AHG, DTT & & 5 & & & & & 2 & 3 & & & \\
\hline CAT-RT & & 7 & & & & 4 & 3 & & & & \\
\hline CAT-AHG (95.8) & & 24 & & & & 1 & 2 & 10 & 7 & 4 & \\
\hline CAT-AHG, DTT & & 5 & & & & & 1 & 3 & 1 & & \\
\hline
\end{tabular}

Bold characters express the allowable range for $\mathrm{ABO} \mathrm{Ab}$ titers according to the technique.

Abbreviations: IS, immediate spin; RT, room temperature incubation; AHG, indirect anti-human globulin test; DTT, treatment with dithiothreitol; CAT, column agglutination technology.

*Percentage of participants within the allowable range.

적혈구 부유액의 용혈을 호소하였기 때문에 혈액형검사에 일 부 영향을 주었을 가능성도 있다. 또한 $\mathrm{ABO}$ 혈액형의 경우 2016년부터 혈구형과 혈청형의 혈구응집을 모두 입력하도록 하였기 때문에 이에 익숙지 않아 최종 혈액형 판정을 제대로
하지 못한 기관도 포함되었기 때문인 것도 완전히 배제할 수 없을 것으로 보인다. 그러나 일부 기관에서는 $\mathrm{ABO}$ 혈액형의 경우 아직도 혈구형검사만 실시하고 있었는데(자료 제시하지 않음), 정확한 혈액형 판정을 위해서는 혈청형검사를 반드시 
시행하여야 하므로 향후에는 혈구형과 혈청형 모두 입력하여 야 최종 혈액형 판정을 할 수 있도록 홍보하고 입력프로그램을 변경할 필요가 있겠다. 또한 최근 검사실의 혈액형검사에 자동 화 장비의 사용이 증가하고 있는 추세이므로 현재 발송되는 검 체는 자동화 장비에 사용할 수 없는 혈장과 적혈구 부유액이므 로 전혈의 형태로 전환하는 것이 바람직하겠다.

교차시험의 평균 정답률은 $95.8 \%$ 로 검사단계와 검사법에 따라 다른 정답률을 보였다. 교차시험 양성 검체는 항글로불린 단계에서만 검출되도록 의도되었으나, 항글로불린 단계가 포 함되지 않은 식염수 단계와 저이온강도식염수 단계에서도 검 출한 기관들이 있으므로 이 기관들이 민감하게 검출하였다기 보다는 오히려 위양성 판정 가능성과 항글로불린 단계의 추가 에 대한 교육이 이러한 기관들에서 필요할 것으로 여겨졌다.

$\mathrm{A}_{2} \mathrm{Bw}$ 형 검체에 대하여 항-B 시약과의 반응이 $3+$ 이상인 기관이 5 기관이나 되는데 이들 기관 모두 정상 $\mathrm{B}$ 형으로 간주 한 기관이 없었으며, 또한 $\mathrm{Bw}$ 형 검체의 경우 항-B 시약에 $3+$ 로 보고한 기관 중 2 기관은 정상 $\mathrm{B}$ 형으로 보고하였다. 따라서 $\mathrm{ABO}$ 아형을 정확히 판정하기 위해서 이들 기관에 대한 혈구 응집 판정기준이나 검사법 과정에 대한 검토가 필요할 것으로 여겨졌다. 1 차와 2 차 검체에 대하여 항- $\mathrm{H}$ 시약의 반응이 $2+$ 이하를 보인 경우가 각각 $37.9 \%$ 와 $25.0 \%$ 이므로 전년도와 마 찬가지로 항-H 시약이 항-A 시약에 비하여 올바른 시약사용 법에 대한 교육이 필요한 것으로 보인다. 항-H 시약은 항-A 시약에 비하여 사용기관이 적었는데, 이는 2014년와 2015년 보고서도에 지적하였듯이 $[1,2]$ 항-H 시약에 대한 식품의약 품안전처 허가를 득한 국내 업체가 없는 실정이기 때문이다. 항-H 시약은 $\mathrm{ABO}$ 아형을 진단하여 환자에게 올바른 혈액형 의 혈액을 수혈하는데 필수적인 시약이므로, 환자들의 안전을 위하여 이러한 희귀 시약들의 허가제도 개선에 대한 협회나 유 관학회의 적극적인 홍보와 요구가 필요할 것으로 여겨졌다.

2차 $\mathrm{Rh} \mathrm{CcEe}$ 항원검사의 검체는 $\mathrm{CDe}$ 형인데 한 기관에 서 항-c에 대하여 trace로 보고하여 이를 항원 양성 여부 를 결정하기가 어려웠다. 본 사업에서는 $\mathrm{Rh} \mathrm{CcEe}$ 항원검사 에 대하여 미국병리협회에서 주관하는 College of American Pathologists 프로그램과 마찬가지로 각 항원의 혈구 응집 정 도만 입력하도록 되어있으나 이 검사의 최종 결과 형식은 이러 한 항혈청의 결과를 바탕으로 항원형을 결정하는 것으로 향후 에는 $\mathrm{Rh} \mathrm{CcEe}$ 의 항원형을 입력하는 칸도 추가가 필요할 것으 로 생각되었다.

약 $\mathrm{D}$ 검사에 참여하는 기관의 약 $24 \%$ 에서 $\mathrm{RhD}$ 혈액형검사 가 음성이고 약 $\mathrm{D}$ 검사에서 양성이었음에도 불구하고 $\mathrm{RhD}$ 양 성으로 보고하였는데, 이는 혈액원에서 약 $\mathrm{D}$ 형에 대하여 $\mathrm{RhD}$
양성이라고 간주하여야 한다는 사실과 혼동하거나[3] 혹은 약 $\mathrm{D}$ 검사의 의미를 제대로 파악하지 못하였기 때문으로 분석된 다. 약 $\mathrm{D}$ 검사에 참여한 대부분의 기관은 의료기관으로 비록 이 기관들의 상당수가 혈액원을 운영하고는 있으나 대부분 수 혈환자를 다루고 있는 기관이다. 이러한 의료기관들은 수혈환 자에서 약 $\mathrm{D}$ 형을 정확히 판정하여 오히려 $\mathrm{RhD}$ 음성에 준하여 야 하므로 이들 기관에 대한 교육이 필요할 것으로 생각되었 다.

2차 때 발송된 재조합 혈장 검체는 발송된 검체에 문제가 있어 비예기항체 선별 및 동정의 양성 검체의 일부가 평가되 지 못하였다. 항혈청에 신선동결혈장을 혼합한 1차의 검체와 는 달리 비용상의 문제로 2 차 시는 항혈청에 식염수를 첨가하 였었다. 특히 동일한 식염수를 첨가하였음에도 불구하고 다 클론 항체인 경우에는 큰 영향이 없었으나 단클론 항체인 경 우에 활성도가 급격히 저하되는 현상을 보였다. 희석된 항체 들은 $(\langle 1 \mathrm{mg} / \mathrm{mL})$ 활성도가 저하되므로, 높은 농도로 보관하 거나 혹은 정제된 소혈청인 bovine serum albumin이나 젤 라틴과 운반 혹은 여과 단백질을 최종 농도가 $0.1 \%-0.5 \%$ 되 도록 첨가할 필요가 있다. 또한 단백질의 변성을 막기 위해서 는 당류(sucrose, trehalose) 혹은 폴리올(polyol, 예 glucerol, sorbitol) 등의 안정제 첨가가 필요하다[4]. 1차 검체는 운반 단백질이나 당류가 포함된 혈장을 혼합하여 항혈청 활성도에 문제가 없었으나 2 차 검체는 이러한 물질 등이 없기 때문에 항 체 활성도가 빨리 소실되어 참여기관의 검사 당시 측정되지 않 은 기관들이 많았던 것으로 분석된다. 따라서 향후에는 특히 단클론 항혈청을 사용할 경우에 이의 희석용액으로 신선동결 혈장을 사용하거나 그렇지 못할 경우에는 운반 단백질과 당류 등의 첨가가 할 필요가 있겠다. 이 검체를 제외하고는 비예기 항체 선별과 동정검사는 우수한 정답률을 보였다.

직접항글로불린 검체의 수가 한 회차당 기존의 2 개에 비하 여 2016년부터 3개로 증가하였는데, 음성 검체의 경우 IgG 단 특이성과 C3d 단특이성의 정답률이 예년에 비하여 증가한 경 향을 보였다.

$\mathrm{ABO}$ 항체 역가검사에 참여하는 기관 수가 전년도 34 개에 서 2016년도에 42개로 증가하였으며, 예년과 마찬가지로 검 사실들은 각기 검사실에 맞추어 여러 가지 측정방법들을 사용 하고 있었다. 1 차와 2 차의 허용범위 내의 정답률이 다양하기 는 하나, 정답률은 전년도와 마찬가지로 미세원주응집법 항글 로불린법이 가장 높았다. 미세원주응집법 항글로불린법의 사 용기관이 시험관 항글로불린법보다 많은데, 현재 국민건강요 양급여 기준으로는 미세원주응집법과 시험관법 등의 검사법 간에 차이가 없다는 문제점이 있다. 기관 간의 차이도 적은 미 


\section{Journal of LABORATORY MEDICINE and QUALITY ASSURANCE}

Young Ae Lim et al • Annual Report (2016) of Transfusion Medicine EQA

세원주응집법을 사용하는 기관들이 증가할 것으로 예상되며, 재료비가 시험관법에 비하여 비싼 미세원주응집법을 이용한 $\mathrm{ABO}$ 항체 역가검사에 대한 적절한 수가체계도 필요한 것으 로 생각되었다.

차세대 신빙도조사사업을 처음으로 시행한 2016년도 4개의 수혈의학프로그램의 10 가지 종목을 시행하였고 이에 대한 결 과를 분석하여 발송하였기에 참여기관들의 검사실 향상에 도 움을 주었을 것으로 평가할 수 있었다.

\section{REFERENCES}

1. Lim YA, Cho HS, Kwon SW, Kwon KC, Kim SY, Park KU, et al. Annual report on the external quality assessment scheme for blood bank tests in Korea (2015). J Lab Med Qual Assur 2016;38:59-67.

2. Lim YA, Oh JS, Kwon SW, Kwon KC, Kim SY, Park KU, et al. Annual report on the external quality assessment scheme for blood bank tests in Korea (2014). J Lab Med Qual Assur 2015;37:47-55.

3. Roback JD; American Association of Blood Banks. Technical manual. 17th ed. Bethesda (MD): American Association of Blood Banks, 2011.

4. Johnson M. Antibody shelf life/how to store antibodies. Mater Methods 2012;2:120.

수혈의학검사 신빙도조사 결과보고(2016)

\section{임영애 - 조현수}

아주대학교 의과대학 아주대학교병원 진단검사의학과

2016년에 시행된 수혈의학검사에 대한 신빙도조사결과를 보고하고자 한다. 검체는 아주대학교 병원에서 직접 제조하여 참여기관들에게 연 2회 발송하였다. 10 개의 평가종목에 대한 정답률 은(평균 참여기관 수) 다음과 같았다. $\mathrm{ABO}$ 혈액형검사 98.9\%-99.7\% (627개), RhD 혈액형검사 98.6\%-99.8\% (607개), 교차시험검사 90.1\%-98.1\% (454개), ABO 아형 혈액형 92.7\%-93.0\% (42 개), Rh CcEe 항원검사 97.8\%-100.0\% (46개), 약 D검사 70.8\%-73.6\% (91개), 비예기항체 선별 검사 96.6\%-100.0\% (267개), 직접항글로불린검사는 다특이성 92.2\%-99.6\% (249개), 단특이성

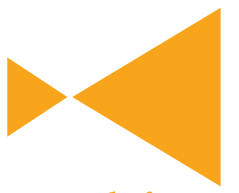

Journal of

LABORATORY MEDICINE and QUALITY ASSURANCE immunoglobulin G 84.1\%-100.0\% (68개), 그리고 단특이성 C3d 80.0\%-100.0\% (68개), 비예기항 체 동정검사 96.7\%-99.1\% (118개), 그리고 ABO 항체 역가검사 82.4\%-100.0\% (42개)였다. 약 D 검사를 제외한 2016년도 수혈의학검사의 신빙도결과는 우수한 편이었으며, 참여 검사실의 질 향상 에 기여하였다.

(J Lab Med Qual Assur 2017;39:107-116)

\section{교신저자: 임영애}

우)16499 경기도 수원시 영통구 월드컵로 164 , 아주대학교 의과대학 아주대학교병원 진단검사의학과 Tel: 031)219-5786, Fax: 031)219-5778, E-mail: limyoung@ajou.ac.kr 